folly and adds error to error. It would seem that the inaccuracy of the ordinary moisture determiration should be recognized although sanctioned officially. This is the least thing which could be asked or done. If it is necessary to have and use methods of a low order of accuracy, the fact ought to be well understood, clearly recognized and the methods used for what they are worth and no more.

\section{ORIGINAL PAPERS.}

\section{THE BAG HOUSE AND ITS RECENT APPLICA- TIONS.}

By W. C. EBAUGH.

Received August 20, 1909.

The recovery of dust and fume from metallurgical operations is one of the most important problems confronting the works' manager. Escaping fume means loss in efficiency of metal extraction and becomes the cause of injury to surrounding property, thereby resulting in suits for damages or for injunctions. The literature relating to smoke damage $^{1}$ is quite extensive, and the numbers of lawsuits in California, Montana, Tennessee and Utah growing out of the question need only to be drawn to our attention in order to impress us with the magnitude of the subject. An excellent résumé of the legal status of the smoke question is given in a recent number of the Engineering and Mining Journal. ${ }^{2}$

In his testimony before the Federal Court for the District of Montana Mathewson gave the following summary of the methods that have been tried to remove fume from smoke: ${ }^{3}$

A.-Cooling processes.

I. Water spray.

2. Admission of air.

3. Radiation.

4. Freezing.

B.--Filtering processes.

I. Bag house.

2. Friction.

3. Centrifugal gas cleaners.

1 See bibliographies in "Rauch-beschädigung," Haselhoff und Lindau (Bornträger, Leipzig); pp. 395-400; Persifor Frazer, Trans. A. I. M. E., 38, 520-555 (1907); Haywood, Bulletins 89 and 113, Bureau of Chemisiry, U. S. Dept. of Aoric.; Haywood, Jour. Amer. Chem, Soc., 29, 998-1009 (1907); Ebaugh, Jour. Amer. Chem. Soc., 29, 951-970 (1907); Harkins and Swain, Jour. Amer. Chem. Soc., 29, 970-998 (1907); 30, 915-946 (1908); Widtsoe, Bulletin 88, Utah Agri. Expt. Sta.

2 Baskerville, Eng. Min. Jour., 87, 884-886 (1909).

3 Eng. Min. Jour., 87, 87 (1909).

\section{C.-Electrostatic process.}

I. Cottrell process.

For reasons that need not be discussed here the cooling processes enumerated above have not been satisfactory when applied to lead and copper smelter smoke. The Cottrell electrostatic process is still in an experinlental stage. Greater success has attended the various filtering processes. The Theisen centrifugal purifiers ${ }^{1}$ and the Osborn purifiers combine the centrifugal action with water spray, and are successful in removing dust from gases, but experiments made in the Salt Lake Valley indicate that such -processes do not remove the fume from lead and copper smelter smoke. The various friction devices, such as Cowper flues, Freudenberg plates, Roesing screens, zigzag flues, etc., also seem to aid in settling the dust, but not in removing fume. It is said that by permitting flue gases to enter expansion chambers ${ }^{2}$ the solids can be settled out if the velocity be reduced sufficiently, but here too the fume escapes. In fact when treated by any of the above mentioned methods the minute particles that constitute the fume seem to act more like insoluble gases than like solids. ${ }^{3}$

For lead and zinc furnaces the bag house has long been recognized as a most efficient means for removing solids from smoke. Beginning with the work of Jones, ${ }^{4}$ who wsed large bags ( $8 \times 70 \mathrm{ft}$.) for filtering zinc fume, Wetherill, and $\mathrm{Hall},{ }^{5}$ who substituted screens in the side of a house for the bags previously employed as filters, we find Percy ${ }^{6}$ suggesting that a fabric might be used for lead fume. The inventions of Lewis and Bartlett (1878, $t$ t seq.), Ward, ${ }^{7}$ Batchman $^{8}$ and Bartlett ${ }^{9}$ led up to the modern bag house as perfected by

${ }^{1}$ Eng. Min. Jour., 70, 607 (1900).

2 Ibid., 80, 695 (1905).

3 The difference in composition between the dust deposited in a flue at a given point and the fume (probably mixed with dust) drawn from the flue at the same point and collected by bag filtration is shown by the following analyses:

(a) Fume from copper blast furnaces

(b) Dust from copper blast furnaces.

(c) Fume from copper converters.

(d) Dust from copper converters.

Sample number......... a

Density in tos. $/ \mathrm{cu} . \mathrm{ft} \ldots \ldots, \quad 12.75$

Gold in ozs./ton......... 0.16

Silver in ozs./ton........ 19.24

Copper in per cent....... 0.49

Lead in per cent......... 31.70

4 U. S. Pat. 8,756 (1852)

${ }_{5}$ U.S. Pat. 72,032 (1667)

B "Metallurgy," p. 449 (1870).

7 U. S. Pat. 381,301 (1888).

8 U. S. Pat. 463,184 (1891).

9 U. S. Pat. 470,970 (1892).

\begin{tabular}{ccc}
$b$ & $c$ & $d$ \\
77.0 & \multicolumn{2}{c}{$c$} \\
0.33 & 0.20 & 6.0 \\
6.17 & 41.40 & 129.60 \\
2.65 & 2.20 & 65.86 \\
3.65 & 40.40 & 2.75
\end{tabular}

2.75 
Iles and his associates. ${ }^{1}$ During the succeeding sixteen years it was generally accepted that the bag house had reached the limit of its development and could be used only for lead and zinc furnace products-not for copper furnaces or for roasters. ${ }^{2}$ Minor mechanical improvements were proposed by Rourke, ${ }^{3}$ Hannay, ${ }^{4}$ Picher and Boss ${ }^{5}$ and others.

The construction of the modern bag house for the Lewis and Bartlett process is so well known that no description of it need be given here. ${ }^{8}$ The lead smelter bag house is somewhat different. ${ }^{7}$ It consists essentially of two chambers, the lower or dust chamber being twelve to sixteen feet from floor to ceiling, and the upper or bag compartment ranging from thirty to forty-five feet in height. The walls and partitions are usually of brick, properly buttressed or held together by tie rods. The dust chamber or smoke cellar is divided by brick partitions into as many compartments as there are flues leading to the bag house, thus enabling a part of the bag house to be shut down without interfering with the rest of it. The ceiling of the smoke cellar is made of iron or steel plate and is provided with a number of nipples or rings projecting into the bag compartment. From supports near the top of the building bags of cotton or wool are hung, and the lower ends of the bags are tied on to the nipples by means of twine, wire, or hoop bands provided with strap clamps. The older bag houses, designed simply to recover the solids because of their value to the smelter, were built with ventilators along the walls and on the roof; but the more recent ones, intended for the protection of adjacent property as well as for the recovery of values, are provided with stacks that carry the filtered gases two or three hundred feet into the air.

Fans capable of moving I 50,000 to 250 , 000 cubic feet of gas per minute force the flue gases, laden with dust and fume, through a number of large pipes or flues into the smoke cellar and through the bags, and the solids are removed so perfectly that the escaping gases are invisible. The ordinary bag house is provided with 3,000 to 4,500 bags,

1 U. S. Pats. $475,774,480,834,484,016,484,017$ (1892).

a Eng. Min. Jour., 80, 55, et seq. (1905); Iles, "Lead Smelting" (1902), pp. 2, 170, 203 and 204.

3 U.S. Pat. 530,553 (1894).

U. S. Pat. 729,492 (1903).

5 U. S. Pat. 735,904 (1903).

B U. S. Pat. 470,970 (1892); Collins, "Metallurgy of Lead" (1899), pp. 72-73; Hofman, "Metallurgy of Lead" (1906), pp. 131-148; Eng. Min. Jour., 83, 937,1033 (1907).

7 U. S. Pat. 484,017 (1892); Eng. Min. Jour., 80, 55 (1905); 83, $1246(1907) ; 84,527,575$ (1907). each bag being about 18 inches in diameter and 30 to 33 feet long. Whereas the earlier bag houses had 750 to I, IOO square feet of filtering surface per ton of charge, modern practice finds 300 to 500 square feet per ton of charge ample. (In zinc filtration a ratio of 150 to 200 square feet of filtering surface per square foot of hearth is customary.)

As a filtering medium cotton cloth having 42 to 50 threads to the linear inch and weighing 0.4 to 0.7 ounce per square foot was largely used. The objection to this material was that when used at a temperature approximating $200^{\circ} \mathrm{F}$. it became brittle and broke, and if used at temperatures near $100^{\circ} \mathrm{F}$. it became weakened by the acid substances in the filtered solids. It was soon learned that bags made of woolen material, like flannel, not only withstood the action of the corrosive agents better than did cotton, but that the woolen fabric retained its elasticity even when used at temperatures of $250^{\circ}$ to $270^{\circ} \mathrm{F}$. Perhaps this is due to the relatively non-volatile oil contained in the wool, or to the nature of the nitrogenous fiber itself. Modern practice, therefore, is to use the expensive woolen bags rather than the cheaper ones made of cotton. To obtain the benefits of wool, but at a less cost, Iles ${ }^{1}$ proposed that a fabric be used in which the warp should be wool and the weft cotton, or vice versa, and Sheedy ${ }^{2}$ suggested that the lower section of a bag should be made of flannel (wool) and the upper portion of muslin (cotton). The most recent experience has shown that vegetable fibers should not be used at all. Even linen thread for stitching is unsatisfactory.

When woolen bags are used a wide range of temperature is permissible. Perhaps $150^{\circ}$ to $175^{\circ}$ $\mathrm{F}$. is safest, but a minimum of $70^{\circ} \mathrm{F}$. and a maximum of $270^{\circ} \mathrm{F}$. have been used. The best practice is to so adjust dampers at the furnaces and in the flues as to maintain the temperature as near $160^{\circ} \mathrm{F}$. as possible. Under these conditions the material collected in the bag will be dry and filtration can go on rapidly. Lead blast-furnace gases are usually so cool that their treatment in a bag house can take place directly, but the gases from copper furnaces and most roasters ordinarily require cooling. This is effected either by a suitable flue system, which must be as elastic as possible, or by the admission of cold air into the flues with the gases.

Until the investigations of Rhoades and Sprague

1 U. S. Pat. 485,797 (1892)

2 U. S. Pat. 480,834 (1892) 
(1907-1908: had shown the possibilities of filtering neutralized gases, the bag house was looked upon as not suited for copper furnace and roaster gases (cf. p. 687 above). These experimenters, impressed with the fact that the bag houses at zinc works were sometimes managed in what seemed to them, as lead and copper smeltermen, a very reckless fashion, yet with little apparent ill effects, conducted an extensive series of investigations with a miniature bag house of the type illustrated by Iles, ${ }^{1}$ but devised independently by them. A variable speed motor drove a fan that drew gases from a flue and then forced them through a four-inch pipe into a cylindrical dust chamber two by five feet. Upon this cylinder were placed two nipples over which bags were tied. Necessary thermometers, manometers and other instruments were provided, and a house of corrugated iron enclosed the whole apparatus. This experimental bag house was set up at various parts of the flue system of a lead and copper smelter, and the effects of the flue gases with their accompanying solids were determined. During this series of tests neutralizing copper blast furnace and lead roaster gases by means of zinc oxide were tried, and the results were
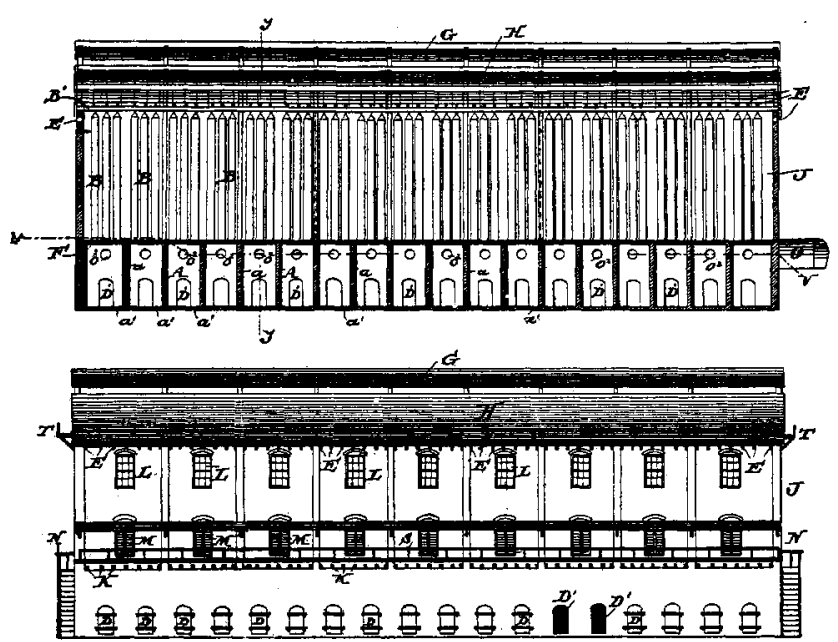

Iles' bag house.

so satisfactory that now the lead plant is operated under conditions suggested by them for filtering all the smoke from the blast-furnaces, hand roasters working on matte and converter or pot roasters charged with ore. Stacks, which under ordinary conditions emit large volumes of dense smoke, send only colorless gases and no solids in to the atmosphere when the bag-filtration plant is used. An

\footnotetext{
1 Eng. Min. Jour., 69, 647 (1900).
}

observer would judge from the appearance of the stacks that the smelter was not running.

Under this system of operation zinc roasting furnaces for the treatment of zinciferous middlings have been erected, and the flue from these furnaces leads directly into the main roaster flue. The middlings, mixed with fuel, are roasted on a grate and the liberated sulphur dioxide and zinc oxide pass into the roaster flue, where the latter oxide neutralizes the corrosive sulphur trioxide that comes from the roasters. Provision is made at the bag house fan for adding ordinary zinc oxide constantly, if need be, by an automatic feeding device.

It would not be economical to use this method, under ordinary conditions, with roasters of the hand or McDougal types, because of the large quantities of sulphur trioxide produced by them; but the treatment of the gases coming from pot or converter roasters presents no difficulties. In these the amount of sulphur trioxide is relatively much less than in the hand or McDougal roaster gases, and zinc oxide neutralization is commercially possible. Were this small amount of sulphur trioxide not to be neutralized, however, the filtering bags would soon be destroyed. ${ }^{1}$ Gases from copper blast-furnaces, reverberatories and converters are amenable to treatment under the conditions herein given.

An item of importance in bag house operation is the means adopted for shaking the bags. Originally the method used was to shut off the gas from a set of bags, open the doors in the bag room, and after the noxious gases had escaped shake the bags by hand. This was at best a disagreeable-even dangerous-task and consumed much time. At East Helena a device was provided whereby an attendant could move a lever on the outside of the bag house and have a set of beaters strike against the rows of bags within. The scheme was abandoned, both because the shaking was ineffectual and the wear and tear on bags was great. Rourke $^{2}$ attached ropes or wires to rings placed around the centers of bags so that a whole row could be shaken by jerking the end of the rope extending outside the building. The most satisfactory device is one designed by Benedict, ${ }^{3}$ in

\footnotetext{
1 Hand roasters present a double difficulty. Not only is the production of $/$ sulphur trioxide large, but the products from coal firing seem to make the bags and their contents liable to spontaneous combustion-a combustion that is not accompanied by flame, but is more like that which one observes in the burning of purik.

2 U. S. Pat. 530,553 (1894).

3 Patent pending.
} 
which the bags are suspended from short levers attached to a central shaft. The outer end of this shaft projects beyond the wall and is provided with a larger lever, so that when this lever is moved to and fro the tops of the bags are given a similar motion, and a wavy motion is imparted to the bags as a whole.

The bag house product, collected in the dust chambers or smoke cellar, usually has a black or dark gray color, is quite light (density less than water) and can be handled with difficulty when in its original state. Therefore it is burned. Some oily waste is lighted and thrown upon it, the doors to the dust chambers are opened, and a fan draws the fumes through a flue situated at the back of the chamber and discharges them into the main flue leading to the bag house. Here the fume evolved during the burning is caught in a part of the house that is operating as usual. The material on the floor of the dust chamber burns slowly like punk, gradually sinters to a product resembling soft lava, and loses some of its arsenic and sulphur. The burning continues a number of days, and then the sintered product goes to an arsenic refinery. The white arsenic is volatilized and used as such, and the residual cinder is charged again into the lead blast-furnace. Thus the arsenic, lead, copper and precious metals are recovered.

The labor question has been a serious one in bag house management, and the expenditure of thought and care upon the welfare of the men is imperative. It will not do to put any kind of a laborer in charge of a bag house. The foreman should be at least as able as the charge floor foreman or the head furnaceman, and his helpers should be capable of understanding orders and executing them implicitly. A wash room divided into three parts should be provided. The laborer enters the "clean room," disrobes and places his clothing in sanitary lockers, passes through the "wash room" into the third room and there dresses in heavy underwear, socks, overalls, jumper, cap, gloves and shoes provided by the company. His shift completed he leaves his working clothes where he got them originally, bathes thoroughly from head to foot, using plenty of soap and hot water, and then passes from the wash room to the locker room he entered at first, and there clothes himself. Constant watchfulness on the part of the management is necessary to make sure that the washing is done regularly and thoroughly. Careful attention must be given to the health of the men, and at the first appearance of arsenical or lead poisoning proper antidotes should be administered and the men ought then to be transferred to some other kind of work until recovery is complete. When regulated as here indicated, the same crew of men can work at a bag house for months at a stretch without discomfort or danger. ${ }^{1}$

The objections to the use of a bag house are ( $\mathrm{I}$ ) cost of installation; ${ }^{2}$ (2) cost of maintenance; (3) artificial draft must be substituted for natural draft; (4) danger to operatives; and (5) the arsenic saved as a by-product is sometimes disposed of with difficulty.

To offset these disadvantages we must consider (I) the greater recovery of metals; (2) regularity in draft and ventilation; (3) greater safety and less discomfort to the inhabitants of the region surrounding the smelter, and consequently less expense for lawsuits.

UNIVERSITY OF UTAH,

Salt Lake City, Utah.

\section{A COMPARISON OF METHODS FOR THE DE- TERMINATION OF SULPHUR IN COAL.}

By S. W. PARR, W. F. WHEELER AND RUTH BEROLzHEIMER.

Received July 10, 1909

Advantage has been taken of a comparative series of tests on thirty-five coals for the determination of calorific values, ${ }^{3}$ to make a further comparison of methods for the determination of sulphur. These methods involve the use of the residues from the bomb calorimeter of the Mahler Atwater type and from the Parr calorimeter, using sodium peroxide as the fusion medium. To these two methods were added the usual Eschka method for the determination of sulphur in coals and the photometric method recently described in the Journal of the American Chemical Society."

While this work was in progress, the article by Holliger $^{5}$ on the estimation of sulphur in coal appeared, in which the same comparison of methods was made, excepting the photometric process. In that article the fusion method by the use of sodium peroxide is discredited as being subjected to too great personal errors. The result of the work described in this paper goes to show the method

1 Some idea as to the dangerous nature of the bag house dust may be gained from the fact that it contains from ten to thirty per cent. of arsenic, and from fifteen to fifty per cent. of lead.

2 A bag house of 4000 bags will cost approximately $\$ 150,000$.

3 "A Series of Parallel Determinations with the Mahler and Parr Calorimeters," This Journat, 1, 673.

4 Jour. Am. Chem. Soc., 26, 1139-43.

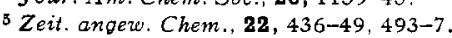

